\title{
Finite Element Analysis of Magnetohydrodynamic Mixed Convection in a Lid-Driven Trapezoidal Enclosure Having Heated Triangular Block
}

\author{
Muhammad Sajjad Hossain 1*, Md. Abdul Alim², Laek Sazzad Andallah ${ }^{3}$ \\ ${ }^{1}$ Department of Arts and Sciences, Ahsanullah University of Science \& Technology (AUST), Dhaka, Bangladesh \\ ${ }^{2}$ Department of Mathematics, Bangladesh University of Engineering \& Technology (BUET), Dhaka, Bangladesh \\ ${ }^{3}$ Department of Mathematics, Jahangirnagar University, Dhaka, Bangladesh \\ Email: ^msh80_edu@yahoo.com, a0alim@gmail.com, andallahls@gmail.com
}

How to cite this paper: Hossain, M.S., Alim, Md.A. and Andallah, L.S. (2020) Finite Element Analysis of Magnetohydrodynamic Mixed Convection in a Lid-Driven Trapezoidal Enclosure Having Heated Triangular Block. American Journal of Computational Mathematics, 10, 441-459.

https://doi.org/10.4236/ajcm.2020.103025

Received: June 11, 2020

Accepted: September 20, 2020

Published: September 23, 2020

Copyright $\odot 2020$ by author(s) and Scientific Research Publishing Inc. This work is licensed under the Creative Commons Attribution International License (CC BY 4.0).

http://creativecommons.org/licenses/by/4.0/

(c) (i) Open Access

\begin{abstract}
A numerical research on magnetohydrodynamic mixed convection flow in a lid-driven trapezoidal enclosure at non-uniform heating of bottom wall has been studied numerically. The enclosure consists of insulated top wall and cold side walls, too. It also contains a heated triangular block $\left(R o t=0^{\circ}-90^{\circ}\right)$ located somewhere inside the enclosure. The boundary top wall of the enclosure is moving through uniform speed $U_{0}$. The geometry of the model has been represented mathematically by coupled governing equations in accordance with proper boundary conditions and then a two-dimensional Galerkin finite element based numerical approach has been adopted to solve this paper. The numerical computations have been carried out for the wide range of parameters Prandtl number $(0.5 \leq P r \leq 2)$, Reynolds number $(60 \leq R e \leq 120)$, Rayleigh number $\left(\mathrm{Ra}=10^{3}\right)$ and Hartmann number $(\mathrm{Ha}=20)$ taking with different rotations of heated triangular block. The results have been shown in the form of streamlines, temperature patterns or isotherms, average Nusselt number and average bulk temperature of the fluid in the enclosure at non-uniform heating of bottom wall. It is also indicated that both the streamlines, isotherm patterns strongly depend on the aforesaid governing parameters and location of the triangular block but the thermal conductivity of the triangular block has a noteworthy role on the isotherm pattern lines. Moreover, the variation of $N u_{a v}$ of hot bottom wall and $\theta_{a v}$ in the enclosure is demonstrated here to show the characteristics of heat transfer in the enclosure.
\end{abstract}

\section{Keywords}

Mixed Convection, Magentohydrodynamic, Finite Element Method, 
Trapezoidal Enclosure, Triangular Block, Non-Uniform Heating

\section{Introduction}

Mixed convection heat transfer within a closed enclosure akin to geometry may occur on account of the combined effect of buoyancy along with shear and nowadays has received substantial attention under the lid-driven enclosure problems. The investigation of flow and heat transfer in lid-driven cavities is the vast studied problems in thermo-fluids area, where configuration of the lid-driven enclosure is encountered in many realistic engineering and industrial applications, such as, contains cooling of electronic devices, materials processing, flow and heat transfer in solar ponds, thermal-hydraulics of nuclear reactors and metal coating, etc. But the intriguing circumstances may occur when an electrically conducting fluid contained by a shear along with buoyancy driven enclosure has been externally applied the magnetic field whereas the magnetic field presents the stability to the flow and to stifles, the heat transfer. The analysis of the above phenomena including a heated obstacle may extend its uses to different other practical situations, while several authors studied recently heat transfer within enclosures, discussed in the following literature.

Transport mechanism of mixed convection within a shear as well as buoyancy-driven cavity had been investigated by Aydin [1] where two different orientations of thermal boundary conditions for the walls of cavity are considered. Aydin and Yang [2] also investigated in a two-dimensional square cavity for mixed convection heat transfer having an aspect ratio of 1 . In this study, the top wall of the cavity is adiabatic. Besides, the isothermal side walls of the cavity have been acting vertically downwards taking uniform velocity. A two-dimensional rectangular cavity for mixed convection heat transfer with constant heat flux from partially heated bottom wall is studied by Guo and Sharif [3] numerically. At the same time, the problem of steady-state two-dimensional flow of mixed convection in a lid-driven differentially heated square cavity had been explored numerically by Oztop and Dagtekin [4]. The viscous dissipation effects of unsteady combined convective flow of water in a rectangular cavity close to its density maximum through isothermal wall were investigated by Hossain and Gorla [5]. After that two-dimensional flow containing a temperature gradient within a two-sided lid-driven cavity was inspected by Luo and Yang [6] numerically. Side by side, Al-Amiri et al. [7] investigated the effects of sinusoidal wavy bottom surface for mixed convection heat transfer in a lid-driven cavity It had been seen that an effective mechanism of heat transfer in the lid-driven cavity was considered for their findings at low Richardson numbers and larger wavy surface amplitudes. Saha et al. [8] inspected numerically the problem of steady-state two-dimensional mixed convection flow in a square enclosure by finding increasing rate of heat transfer for dominant inside heat generation. Nasrin and Parvin [9] studied the 
hydromagnetic effect on the flow of mixed convection in a lid-driven cavity where wavy bottom wall is sinusoidal and found the highest rate of heat transfer at the smallest magnetic effect. Bhattacharya et al. [10] analyzed steady-state flow structures and patterns of temperature for mixed convection within a lid-driven trapezoidal cavity. It is noted that non-isothermal foot wall guides to numerous steady states in either natural convection dominated system. or mixed convection regime in convection subjugated regime of heat transport. Chattopadhyay and Pandit [11] examined flows of mixed convection in a lid-driven porous trapezoidal enclosure numerically using suggested higher order compact. Basak et al. [12] also studied heatline patterns via heat flow on natural convection within trapezoidal enclosure for various inclination angles $\phi$. Heat transfer of mixed convection in a two-dimensional lid-driven trapezoidal enclosure having nanofluids heated from underneath wall is studied by Kareem et al. [13] numerically. It is seen from the flow path that the opposing flow is lower than the helping flow which also presents Nusselt number. Uddin et al. [14] described unsteady flow for double diffusive mixed convection by using the influence of magnetic field within a trapezoidal enclosure and found strength mass transfer which depends on Lewis number. Hossain and Alim [15] [16] studied on magneto-hydrodynamics natural convection within trapezoidal cavity based on heatline analysis with uniformly and non-uniformly heated bottom wall. After that Hossain et al. [17] investigated natural convection flow in a trapezoidal cavity and analyzed heat flow patterns for different positions of heated triangular obstacle in an inclination angles $\phi$. Mixed convection within a trapezoidal lid-driven cavity with nano-fluids has been investigated by Selimefendigil et al. [18] for the diverse connected parameters for example elastic side surface module, Richardson number, side wall inclination angle and solid particle volume fraction. Gangawane [19] studied on mixed convection to find the heat transfer characteristics by the influence of Prandtl and Grashof numbers in a lid-driven square cavity incorporating triangular block along with constant heat flux. At the same time, Gangawane et al. [20] performed on mixed convection flow by the way of finding location and size of triangular obstruct in a lid-driven square cavity. Selimefendigil and Öztop [21] explored flow on mixed convection with $\mathrm{Al}_{2} \mathrm{O}_{3}$-water nanofluid in a lid driven trapezoidal cavity having the effect of an disposed magnetic field numerically. It was determined that the idyllic magnitude of magnetic penchant angle is depending on the model of electrical conductivity. Mehmood [22] presented mixed convection heating flow filled with porous matrix in the two captured MHD trapezoidal cavities where kerosene-cobalt ferrofluid is used. From the result found the prototypes of vitality as well as fluid flow which are notably reliant on the solid ferro particles concentration, Darcy, Grashof in accordance with Hartman numbers. Haq and Aman [23] also investigated water functionalized $\mathrm{CuO}$ nanoparticles filled in a partially heated trapezoidal cavity with inner heated obstacle and found stronger flow and thermal field owing to enhance in Rayleigh number. Çolak et al. [24] then per- 
formed magneto-hydrodynamic mixed convection within a chamfered partially heated lid-driven square cavity. It is indicated that no corner vortex is present and also chamfer may block the key stream and decrease the rate of heat transfer up to $11 \%$.

According to the above literature review, much studies have been found on mixed convection within a lid-driven square cavity but no attention has been paid to the problem of magneto-hydrodynamic mixed convection flow within a trapezoidal cavity embedded inside heated triangular block of different rotations $\left(R o t=0^{\circ}-90^{\circ}\right)$ with practical applications which are also necessary to investigate. The trapezoidal cavity is considered here for an inclination angle $\phi=30^{\circ}$. For this, the present work has been arranged by entire thoughtful about the problem geometry, solution procedure and detailed inspection to provide the results via the fluid flow and heat transfer. In the present investigation, transport phenomena for different rotations of heated triangular obstacle will be explained by using the various non-dimensional parameters. These types of parameters are Prandtl number, Reynolds number, Rayleigh number and Hartmann number. Here Reynolds number is varied from 60 to 120 to simulate forced convection, mixed convection and natural convection dominated flow within the enclosure. The Rayleigh number and Hartmann number are taken as $10^{3}$ and 20 respectively. The Prandtl number has been considered from 0.5 to 2 for fluids.

\section{Problem Specification}

The physical situation of a two-dimensional lid-driven trapezoidal cavity of length $L$ and height $H$ has been depicted schematically in Figure 1 for mixed convection flow through magnetic field of strength $\left(B_{0}\right)$ with the left wall inclined at an angle $\phi=30^{\circ}$ along with $Y$ axis entrenched inside for various rotations $\left(0^{\circ} \leq \operatorname{rot} \leq 90^{\circ}\right)$ of heated $\left(T_{h}\right)$ triangular block. The velocity components correspondingly are $u$ and $v$ along $x$-direction and y-direction. The top wall of the trapezoidal enclosure is moving with a constant velocity $U_{0}$ along the positive direction of $x$-axis. No-slip boundaries are simultaneously considered for three left, right and bottom walls. The top lid is kept at insulated $\left(T_{i}\right)$ while bottom wall is non-uniformly heated $\left(T_{h}\right)$ and side walls are cold $\left(T_{c}\right)$ and $T_{h}>T_{c}$.

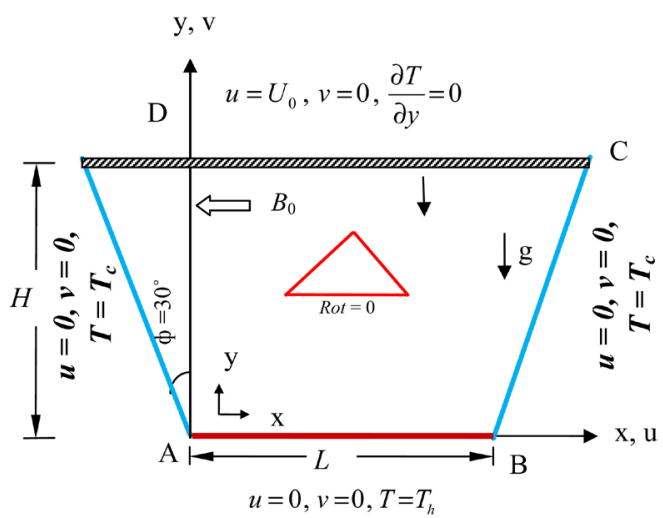

Figure 1. Schematic diagram of Lid-driven Trapezoidal enclosure. 
The fluid is considered for different Prandtl number $(0.5 \leq \operatorname{Pr} \leq 2)$, Reynolds number $(60 \leq R e \leq 120)$, keeping fixed Hartmann number $(H a=20)$ and Rayleigh number $\left(R a=10^{3}\right)$. The fluid flow is supposed to be laminar, incompressible and Newtonian.

\section{Governing Equations}

To solve the problems of fluid flow and heat transfer, the basic laws are utilized ignoring the viscous dissipation term, joule heating term in the energy equation. In the momentum equation, Boussinesq approximation is employed for the variations of density as a function of temperature. Also, the buoyancy force is included as a body force in the y-momentum equation for laminar incompressible thermal flow. The non-dimensional principal equations for two dimensional steady-state MHD mixed convection thermal flow in a lid-driven trapezoidal cavity are stated as follows:

$$
\begin{gathered}
\frac{\partial U}{\partial X}+\frac{\partial V}{\partial Y}=0 \\
U \frac{\partial U}{\partial X}+V \frac{\partial U}{\partial Y}=-\frac{\partial P}{\partial X}+\frac{1}{R e}\left(\frac{\partial^{2} U}{\partial X^{2}}+\frac{\partial^{2} U}{\partial Y^{2}}\right) \\
U \frac{\partial V}{\partial X}+V \frac{\partial V}{\partial Y}=-\frac{\partial P}{\partial Y}+\frac{1}{R e}\left(\frac{\partial^{2} V}{\partial X^{2}}+\frac{\partial^{2} V}{\partial Y^{2}}\right)+\operatorname{RaPr} \theta-\frac{H a^{2}}{R e} V \\
U \frac{\partial \theta}{\partial X}+V \frac{\partial \theta}{\partial Y}=\frac{1}{\operatorname{RePr}\left(\frac{\partial^{2} \theta}{\partial X^{2}}+\frac{\partial^{2} \theta}{\partial Y^{2}}\right)}
\end{gathered}
$$

\subsection{Non-Dimensional Variables}

Non-dimensional variables are used for making the dimensionless governing Equations (1)-(4) stated as follows:

$$
X=\frac{x}{L}, Y=\frac{y}{L}, U=\frac{u}{U_{0}}, V=\frac{v}{U_{0}}, P=\frac{p}{\rho U_{0}^{2}}, \theta=\frac{T-T_{c}}{T_{h}-T_{c}}
$$

The dimensionless governing parameters in the above Equations (1) to (4) are the Reynolds number $R e$, Grashof number Gr, Prandtl number Pr and Rayleigh number $R$ a. and defined as follows:

$$
R e=\frac{U_{0} L}{v}, \operatorname{Pr}=\frac{v}{\alpha}, G r=\frac{\beta g \Delta T L^{3}}{v^{2}}, H a^{2}=\frac{\sigma B_{0}^{2} L^{2}}{\mu}, R a=G r \times \operatorname{Pr}
$$

where $\Delta T=T_{h}-T_{c}$ and $\alpha=\frac{\kappa}{\rho C_{p}}$ are the temperature difference and thermal diffusivity of the fluid respectively.

\subsection{Boundary Conditions}

The dimensionless boundary conditions under consideration can be written as follows:

On the bottom wall: $U=1, V=0, \theta=\sin (\pi X), \forall X=[0,1], Y=0$ 
On the left wall: $U=0, V=0, \theta=0, \forall Y=[0,1]$

On the right wall: $U=0, V=0, \theta=0, \forall Y=[0,1]$

On the top wall: $U=0, V=0, \frac{\partial \theta}{\partial N}=0, \forall Y=1$

On the different orientations of triangular block (obstacle) surface:

$$
U=0, V=0, \theta=1
$$

where $N$ is the non-dimensional distances either along $X$ or $Y$ direction acting normal to the surface. According to Singh and Sharif [25] the average Nusselt number at the heated wall of the cavity based on the non-dimensional variables may be expressed as

$$
N u_{a v}=\int_{0}^{1}\left(\frac{\partial \theta}{\partial Y}\right)_{y=0} \mathrm{~d} X
$$

where $N u_{\text {local }}=-\frac{\partial \theta}{\partial Y}$ and the average bulk temperature is defined as

$$
\theta_{a v}=\int \theta \mathrm{d} \bar{V} / \bar{V},
$$

where $\bar{V}$ is the cavity volume.

\section{Grid Size Sensitivity Test}

A grid size sensitivity test has been conducted for a triangular obstructed lid-driven trapezoidal enclosure $\left(\phi=30^{\circ}\right)$ being there with magnetic field at relevant values of $P r=0.7, R e=100, r o t=0^{\circ}, H a=20$ and $R a=10^{3}$ to attain the appropriate grid size. The following seven different meshes has been taken for the grid size sensitivity test through the following nodes and elements: 5085 nodes, 750 elements; 8415 nodes, 1244 elements; 13,249 nodes, 1978 elements; 14,601 nodes, 2186 elements; 14,757 nodes, 2210 elements; 18,316 nodes, 2757 elements; 21,277 nodes, 3212 elements. The mesh size of 14,757 nodes 2210 elements are selected to find the satisfactory solution for the base case problem as presented in Table 1 and the solution in $\mathrm{Nu}$ had been found to be independent mesh size with further enhance of grid modification.

\section{Numerical Validation}

In order to check the accuracy, validation is the necessary part for the numerical investigation. Since the code validation against experimental data is not probable for the present study, for this, the numerical code is compared within a trapezoidal enclosure $\left(\phi=30^{\circ}\right)$ for $\operatorname{Pr}=0.7$ and. $R a=10^{5}$ as reported by Basak et al.

Table 1. Grid size sensitivity test for the rotations of heated triangular obstacle $\left(\operatorname{Rot}=0^{\circ}\right)$ in a trapezoidal cavity when $\operatorname{Pr}=0.7, P h i=30^{\circ}, H a=20, \operatorname{Re}=100$ and $R a=10^{3}$.

\begin{tabular}{cccccccc}
\hline $\begin{array}{c}\text { Nodes } \\
\text { (Elements) }\end{array}$ & $\begin{array}{c}5085 \\
(750)\end{array}$ & $\begin{array}{c}8415 \\
(1244)\end{array}$ & $\begin{array}{c}13,249 \\
(1978)\end{array}$ & $\begin{array}{c}14,601 \\
(2186)\end{array}$ & $\begin{array}{c}14,757 \\
(2210)\end{array}$ & $\begin{array}{c}18,316 \\
(2757)\end{array}$ & $\begin{array}{c}21,277 \\
(3212)\end{array}$ \\
\hline $\mathrm{Nu}$ & 6.841483 & 8.025347 & 8.043388 & 8.042868 & 8.042316 & 8.045789 & 8.04712 \\
Time $(\mathrm{s})$ & 4.717 & 7.18 & 11.206 & 12.227 & 12.838 & 15.833 & 19.328 \\
\hline
\end{tabular}


[12]. The result is shown in Figure 2 and also is benchmarked. Nevertheless, almost similar experimental results for square enclosure with discrete bottom heating attained by Corvaro and Paroncini [26] are compared by the current code and shown in Table 2. It has been found excellent agreement which validates the present numerical computations and provides us confidence to use the current code.

\section{Method of Solution}

The solution of the dimensionless governing equations associated with its proper boundary conditions is explained by the Galerkin finite element formulation. The continuum domain is alienated into small units of non-overlapping areas, defined as elements. Six node triangular elements with quadratic interpolation functions are used to improve the finite element equations. All nodes are associated with velocity and temperature and then linear interpolation functions for pressure are employed to discretize the domain. Furthermore, interpolation functions, such as, local normalized elements have been used to estimate the contingent variables in each element. By substituting the acquired approximations in the governing equations along with boundary conditions, residuals for each of the conservation equations are yielded and then reduced to zero in a weighted sense over each element volume using the Galerkin method. The description of this method is already discussed in detail by Dechaumphai [27], Taylor and Hood [28] and Reddy [29].

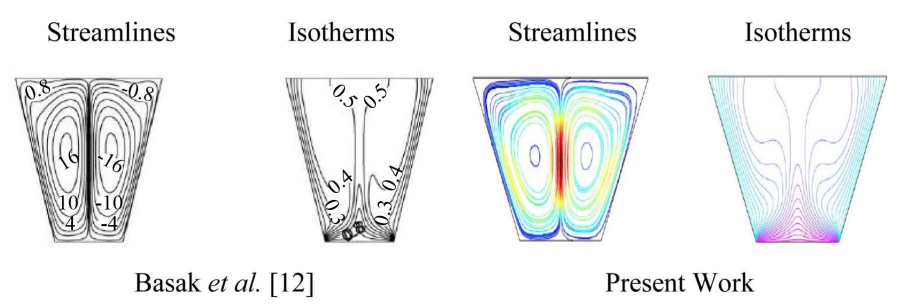

Figure 2. Comparison results between present work and Basak et al. [12] for isotherms and streamlines with uniform bottom heating at $\psi=0, \phi=30^{\circ}, \operatorname{Pr}=0.7, \operatorname{Ra}=10^{5}$.

Table 2. Comparison results between experimental (exp.) data and present numerical data of average Nusselt number for discrete isothermal heat source size $=0.2, \psi=0$ and $\phi$ $=0^{\circ}$.

\begin{tabular}{ccccc}
\hline$R a$ & $\begin{array}{c}\text { Numerical Data } \\
\text { Corvaro and } \\
\text { Paroncini [26] }\end{array}$ & $\begin{array}{c}\text { Experimental Data } \\
\text { Corvaro and } \\
\text { Paroncini [26] }\end{array}$ & $\begin{array}{c}\text { Present } \\
\text { Numerical Data } \\
\text { (current code) }\end{array}$ & $\begin{array}{c}\text { Error (\%) } \\
\text { (Experimental } \\
\text { and Present data) }\end{array}$ \\
\hline $7.56 \times 10^{4}$ & 5.12 & 4.80 & 5.29 & -10.21 \\
$1.38 \times 10^{5}$ & 5.86 & 5.859 & 6.1 & -4.09 \\
$1.71 \times 10^{5}$ & 6.2 & 6.30 & 6.38 & -1.26 \\
$1.98 \times 10^{5}$ & 6.28 & 6.45 & 6.55 & -1.55 \\
$2.32 \times 10^{5}$ & 6.4 & 6.65 & 6.79 & -2.11 \\
$2.5 \times 10^{5}$ & 6.5 & 6.81 & 6.91 & -1.47 \\
\hline
\end{tabular}




\section{Results and Discussions}

A numerical study on the flow of mixed convection in presence of magnetic field (MHD) in a lid-driven trapezoidal enclosure $\left(\phi=30^{\circ}\right)$ enclosing different rotations of heated triangular block or obstacle $\left(\operatorname{Rot}=0^{\circ}-90^{\circ}\right)$ has been presented here. The analysis has been conducted for the various ranges of non-dimensional parameters such as Rayleigh number $\left(R a=10^{3}\right)$, Hartmann number $(H a=20)$, Prandtl number $(0.5 \leq P r \leq 2)$, and Reynolds number $(60 \leq R e \leq 120)$ as well as various rotations of heated triangular block within trapezoidal cavity. The numerical results have been displayed in terms of both streamlines and isotherms and the rate of heat transfer characteristics such as average Nusselt numbers and average bulk temperature as well as different rotations of heated block or obstacle.

\subsection{Effect of Rayleigh Number: Streamlines, Isotherms and Heat Transfer Rates Varying Rotations of Triangular Block}

The numerical results have been presented the impact of Reynolds number on the structure of fluid flow and isotherm distributions of MHD mixed convection flow in a lid-driven trapezoidal enclosure in Figures 3-7 for the assorted values of Reynolds number ( $R e=60-120)$ varying different rotations or orientations of heated triangular obstacle $\left(\operatorname{Rot}=0^{\circ}-90^{\circ}\right)$ keeping fixed Rayleigh

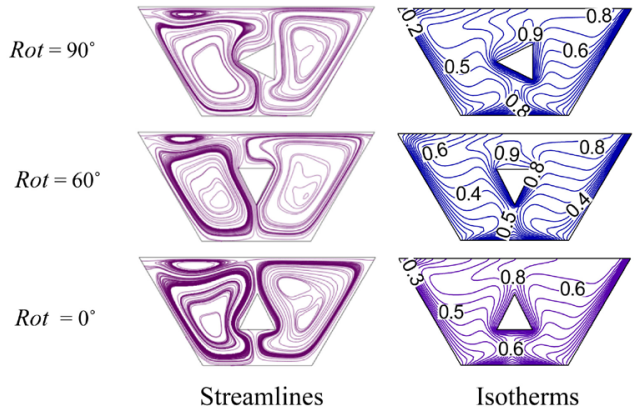

Figure 3. Streamlines and isotherms for various rotations or orientations of heated triangular block $\left(\operatorname{Rot}=0^{\circ}-90^{\circ}\right)$ at $\mathrm{Re}=60$ with non-uniform bottom heating while $\mathrm{Ha}=$ 20, $R a=10^{3}, \operatorname{Pr}=0.7$.

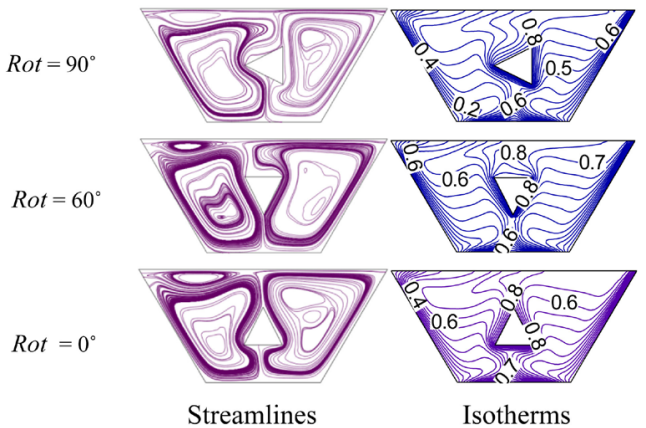

Figure 4. Streamlines and isotherms for various rotations or orientations of heated triangular block $\left(\operatorname{Rot}=0^{\circ}-90^{\circ}\right)$ at $\mathrm{Re}=70$ with non-uniform bottom heating while $\mathrm{Ha}=20$, $R a=10^{3}, \operatorname{Pr}=0.7$. 


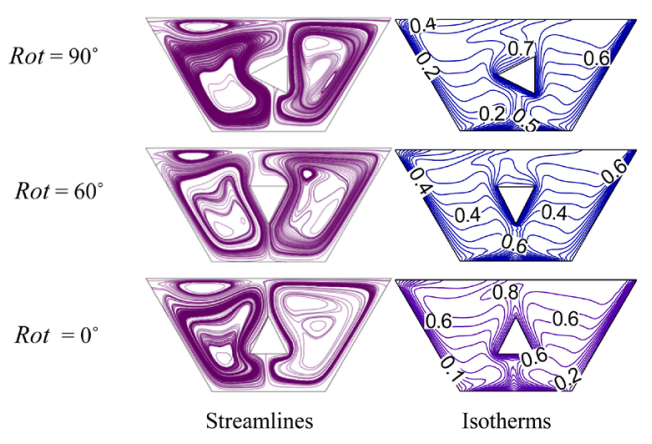

Figure 5. Streamlines and isotherms for various rotations or orientations of heated triangular block $\left(\operatorname{Rot}=0^{\circ}-90^{\circ}\right)$ at $\mathrm{Re}=90$ with non-uniform bottom heating while $\mathrm{Ha}=$ 20, $R a=10^{3}, \operatorname{Pr}=0.7$.

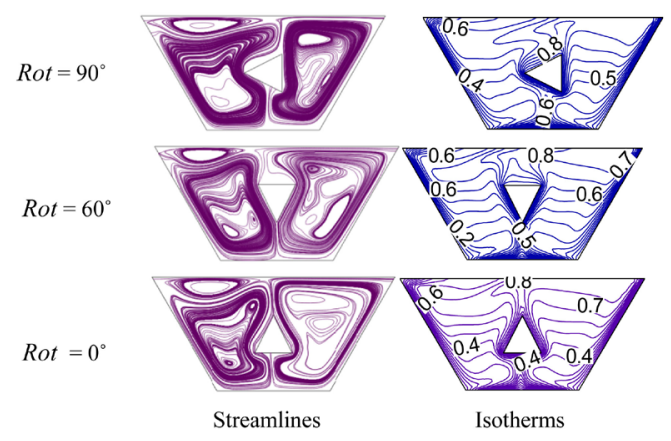

Figure 6. Streamlines and isotherms for various rotations or orientations of heated triangular block $\left(\operatorname{Rot}=0^{\circ}-90^{\circ}\right)$ at $\mathrm{Re}=110$ with non-uniform bottom heating while $\mathrm{Ha}=$ $20, R a=10^{3}, \operatorname{Pr}=0.7$.

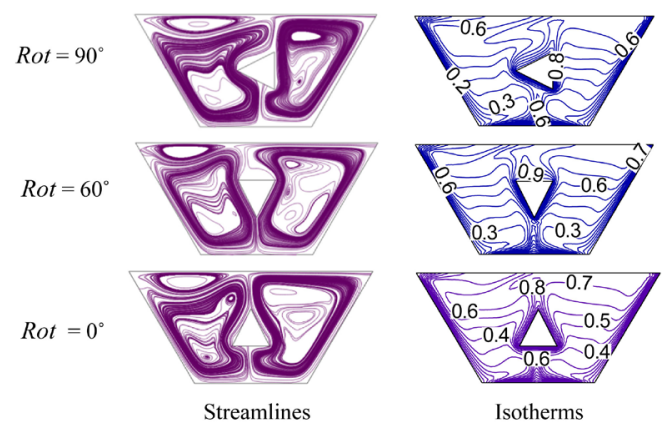

Figure 7. Streamlines and isotherms for various rotations or orientations of heated triangular block $\left(\operatorname{Rot}=0^{\circ}-90^{\circ}\right)$ at $\mathrm{Re}=120$ with non-uniform bottom heating while $\mathrm{Ha}=$ $20, R a=10^{3}, \operatorname{Pr}=0.7$.

number $\left(\mathrm{Ra}=10^{3}\right)$, Hartmann number $(\mathrm{Ha}=20)$ and Prandtl number $(\operatorname{Pr}=$ $0.7)$.

At relatively little Reynolds number $(R e=60)$, it has been seen from Figure 3 that there exist three eddy circulation cells for different rotations or orientations of heated triangular block or obstacle $\left(\operatorname{Rot}=0^{\circ}-90^{\circ}\right)$ while $\mathrm{Ha}=20, \mathrm{Ra}=10^{3}$ and $\mathrm{Pr}$ $=0.7$. Within these cells, a symmetrical clockwise (CW) and anti-clockwise (ACW) cells developed near the left and right walls inside the enclosure correspondingly when $R o t=0^{\circ}$. But when the rotations of the heated triangular block 
changes its position inside the enclosure, an anti-clockwise cell formed in the right side of the wall taking maximum part and clockwise cells developed near the left wall and also left-top wall of the enclosure for Rot $=60^{\circ}$. When $R o t=90^{\circ}$ then it is viewed that a clockwise cells occupy the more part of the enclosure where two recirculation cells are present and another anti-clockwise cell developed near the right wall of the enclosure. By this, a well mixture fluid within the enclosure has been implied. Besides, the secondary vortices are found inside the primary cells of the enclosures. It is also seen from Figure 4 that eddy circulations near the left and right walls look like spade shape when $R o t=0^{\circ}$ but when $R o t=60^{\circ}$ then the circulations near the left and right walls looks like respectively parallelogram shaped and gun shaped and also for $R o t=90^{\circ}$, the circulations near the left and right walls looks like respectively mango shaped. But one oval circulation cell has been observed in the left-top corner side of the enclosure. Moreover, denser heating lines have been observed for $R o t=0^{\circ}, 60^{\circ}$ but less dense heating lines are observed for Rot $=90^{\circ}$. This type of behavior happens logically because of changing of positions of heated triangular block inside the enclosure gives the available space in favor of the buoyancy-induced recirculation. With the aid of enhancing values of $\operatorname{Re}(\operatorname{Re}=70-120)$ it has been noticed similar types of clockwise and anti-clockwise cells for different orientations of heated triangular block $\left(R o t=0^{\circ}, 60^{\circ}, 90^{\circ}\right)$ in Figures 4-7. Dense heating lines are being increased fastly for increasing values of $R e$. Besides the secondary vortices varying diverse orientations of heated triangular obstacle are growing more for increasing the magnitudes of $R e$ and too watched more packed secondary vortices to the relevant walls which imply that the flow of the fluid moves faster and the velocity of boundary layer develop into thinner. In addition, it has been clearly seen bigger vortex in the left-top side of the enclosure for increasing of Re varying heated triangular obstacle $\left(\operatorname{Rot}=0^{\circ}, 60^{\circ}, 90^{\circ}\right)$ in consequence of steadily conduction intensified.

The corresponding isotherm distributions have been shown in the Figure 3-7 for the different values of Reynolds number $(60-120)$ varying a variety of rotations or orientations of heated triangular block $\left(\operatorname{Rot}=0^{\circ}-90^{\circ}\right)$ while $\operatorname{Pr}=0.7$, $H a=20$ and $R a=10^{3}$. From these figures, it has been found compacted isotherm lines at the heated wall of the enclosure in accordance with around the heated wall of the triangular block, testifies the noticeable strong influence of convective heat exchange. Isotherm lines are also parallel near the side walls. It is also viewed that isotherm distributions around the heated triangular block and too from the non-uniform heating of the base wall which explains pure conduction heat transfer. Besides isotherm distributions are getting shifted towards the side (left and right) walls of the enclosures symmetrically on account of slight stronger convection.

The numerical results of average Nusselt number $\left(N u_{a v}\right)$ at the non-uniform heating of bottom wall and average bulk temperature $\left(\theta_{a r}\right)$ of the enclosure varying assorted rotations or orientations of heated triangular block (Rot $=0^{\circ}$ $90^{\circ}$ ) have been displayed in Figure 8(a) and Figure 8(b) against Reynolds 


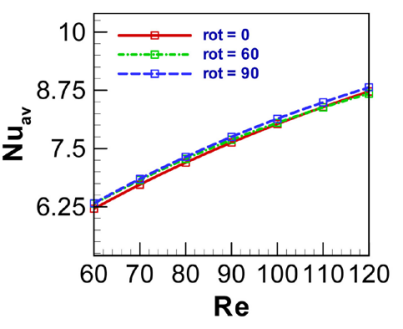

(a)

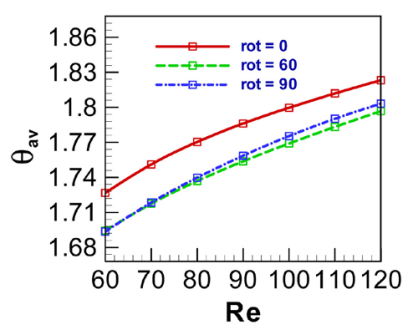

(b)

Figure 8. Variations of different rotations or orientations of heated triangular block (Rot $\left.=0^{\circ}-90^{\circ}\right)$ on (a) average Nusselt number $\left(\mathrm{Nu}_{\mathrm{av}}\right)$ and (b) average bulk temperature $\left(\theta_{\mathrm{av}}\right)$ against at various $60 \leq \mathrm{Re} \leq 120$ with non-uniform bottom heating while $\mathrm{Ha}=20, \mathrm{Ra}=$ $10^{3}, \operatorname{Pr}=0.7$.

number. It is noticed from Figure $8(\mathrm{a})$ that average Nusselt number $\left(N u_{a v}\right)$ for different orientations of heated triangular block $\left(\right.$ Rot $\left.=0^{\circ}-90^{\circ}\right)$ increases by increasing the values of $R e$ which shows the convective heat transfer Phenomenon. It is also noticed that $N u_{a v}$ is higher for $R o t=90^{\circ}$ and almost lesser for $R o t=60^{\circ}$ means that heat transfer rate is changing by the effect of change of locations of heated triangular obstacle. On the other hand, it is observed from Figure 8(b) that average bulk temperature for diverse orientations of heated triangular block also enhances due to raise of $R e$. It is interesting to notice that average bulk temperature carried out the upper value for $R o t=0^{\circ}$ shows the convective current. It is also observed that average temperature behaves conduction-like distribution at $R o t=60^{\circ}, 90^{\circ}$ when $R e=80$ and after that starts the convection due to more heat source for $R o t=60^{\circ}, 90^{\circ}$ when $R e>80$, that is, average temperature is affected by the rotations of heated triangular block.

\subsection{Effect of Prandtl Number: Streamlines, Isotherms and Heat Transfer Rates Varying Rotations of Triangular Block}

The numerical results on the streamlines as well as isotherm distributions for the considered different orientations of heated triangular block $\left(\right.$ Rot $\left.=0^{\circ}-90^{\circ}\right)$ are illustrated in Figures 9-12 for the effect of Prandtl number $(\operatorname{Pr}=0.5-2)$ while $H a=20, R a=10^{3}$ and $R e=60$.

From Figure 9, it has been found that three recirculation cells have been made at small $P r=0.5$ whereas two symmetrical types of recirculation cells in the left and right walls and the rest one cell in the left-top corner wall of the enclosure for $R o t=0^{\circ}, H a=20, R a=10^{3}$ and $R e=60$. This means that the flow is influenced by the buoyancy force. One oval vortex is seen inside the left eddy circulations while one tiny vortex inside the right eddy circulations. It is also found dense circulations near the left wall of the enclosure. When the rotations of heated triangular block changes its location $\left(\operatorname{Rot}=60^{\circ}, 90^{\circ}\right)$, it is noticed that number of eddy circulation cells reduce and then found two recirculation cells. It has been noticed that right eddy circulations occupy the maximum part of the cavity and the left eddy circulation cell occupies the rest part of the cavity. Moreover dense circulations also reduce by the effect of heated triangular 


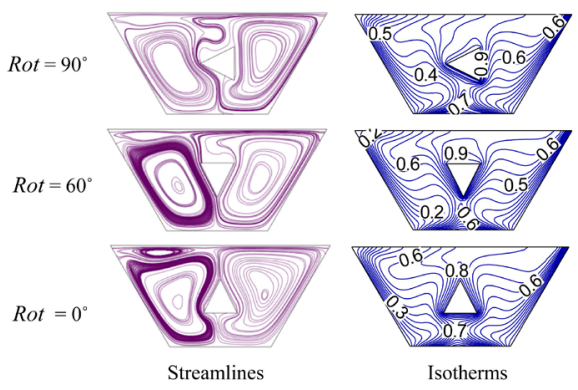

Figure 9. Streamlines and isotherms for a range of rotations or orientations of heated triangular block $\left(\operatorname{Rot}=0^{\circ}-90^{\circ}\right)$ at $\mathrm{Pr}=0.5$ with non-uniform bottom heating while $\mathrm{Ha}=$ 20, $R a=10^{3}, \operatorname{Re}=60$.

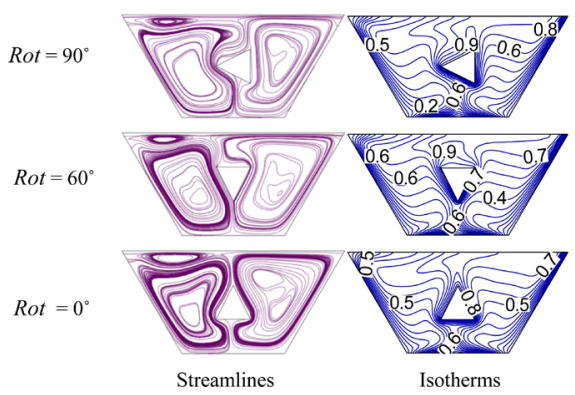

Figure 10. Streamlines and isotherms for a range of rotations or orientations of heated triangular block $\left(\operatorname{Rot}=0^{\circ}-90^{\circ}\right)$ at $\mathrm{Pr}=0.7$ with non-uniform bottom heating while $\mathrm{Ha}=$ $20, R a=10^{3}, \operatorname{Re}=60$.

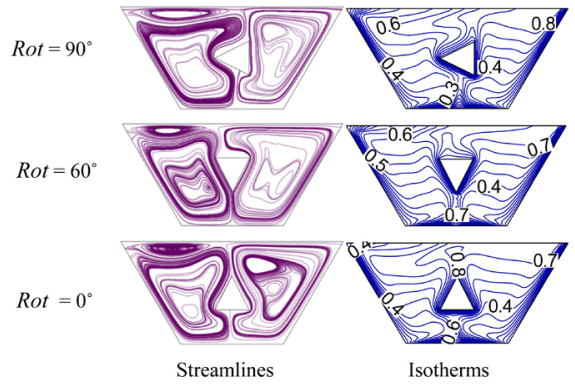

Figure 11. Streamlines and isotherms for a range of rotations or orientations of heated triangular block $\left(\operatorname{Rot}=0^{\circ}-90^{\circ}\right)$ at $\mathrm{Pr}=1.0$ with non-uniform bottom heating while $\mathrm{Ha}=$ 20, $R a=10^{3}, \operatorname{Re}=60$.

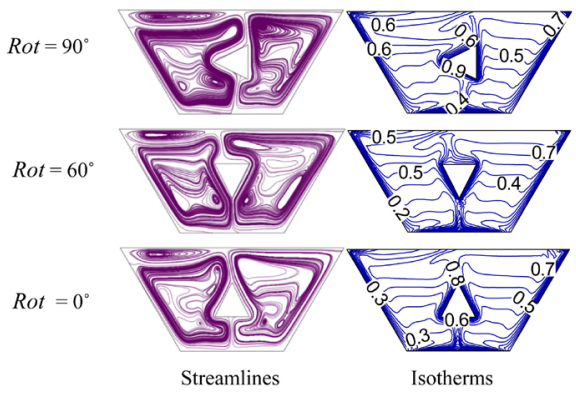

Figure 12. Streamlines and isotherms for various rotations or orientations of heated triangular block $\left(\operatorname{Rot}=0^{\circ}-90^{\circ}\right)$ at $\operatorname{Pr}=2.0$ with non-uniform bottom heating while $\mathrm{Ha}=$ $20, R a=10^{3}, \operatorname{Re}=60$. 
obstacle. Owing to increase of Prandtl number $(\operatorname{Pr}=0.7-2)$, it has been perceived from Figures 10-12 that similar types of recirculation cells like Figure 1 are formed. But left eddy circulation cells take maximum part for Rot $=90^{\circ}$ which happens due to increase of Pr. It has been observed left-top side recirculation cells for all cases of heated triangular obstacle $\left(\right.$ Rot $\left.=0^{\circ}-90^{\circ}\right)$ due to enhance of $P r$, which implies the stronger convection in the enclosure due to heat source. Moreover it is seen that the size of left-top side circulation cells decreases by the affect of heated triangular obstacle. The thickness of thermal boundary layer decreases as expected due to enhance of $P r$ as well as the variations of rotations or orientations of heated triangular block.

The isotherm distributions with the rotations of heated triangular obstacle $\left(\right.$ Rot $\left.=0^{\circ}-90^{\circ}\right)$ are illustrated in Figures 9-12 for different $\operatorname{Pr}(\operatorname{Pr}=0.5-2)$ by the way of temperature field in the separate flow area where while $H a=20, R a=$ $10^{3}$ and $R e=60$. At low $P r=0.5$, it is seen that isotherm lines are smooth curves at the heated bottom wall as well as around the heated triangular obstacle ( $R o t=$ $0^{\circ}-90^{\circ}$ ) and isotherm lines is pushed into near the side walls by the effect of a slighter convection of flow. It is observed that isotherm lines are compacted near the side walls. With the aid of increasing $P r$, it is also observed linear isotherm lines in the enclosure and then impenetrable to the respective side walls. It can easily be noticed that isotherms for various $\operatorname{Pr}$ are seen to be clustered around the heated triangular block of the enclosure, near the heated base wall as well as cooled side walls of the enclosure, implying the shear temperature gradient beside the upright direction within this field. Furthermore the thinner thermal boundary layer is seen near the heated wall of the enclosure with the increasing Pr.

Figure 13(a) and Figure 13(b) display the numerical results of average Nusselt number $\left(N u_{a r}\right)$ at the heated surface and average bulk temperature $\left(\theta_{a v}\right)$ of the cavity having different orientations of heated triangular block (Rot $=0^{\circ}$ $90^{\circ}$ ) for various $\operatorname{Pr}$ where $H a=20, R a=10^{3}$ and $R e=60$. It has been observed from Figure 13(a) that average Nusselt number raise harshly by increasing $P r$. It has been clearly found from Figure 13(a) that heat transfer rates are maximum

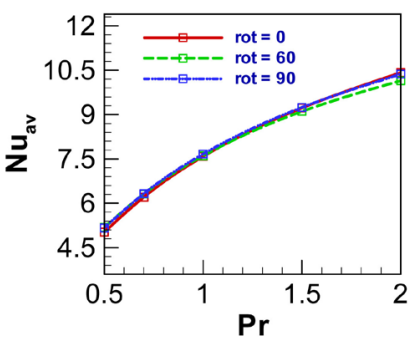

(a)

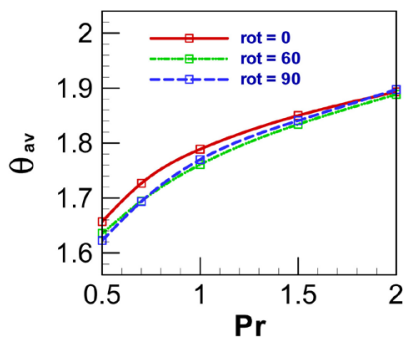

(b)

Figure 13. Variations of different rotations or orientations of heated triangular block $\left(R o t=0^{\circ}-90^{\circ}\right)$ on (a) average Nusselt number $\left(\mathrm{Nu}_{\text {av }}\right)$ and (b) average bulk temperature $\left(\theta_{\text {av }}\right)$ against at a range of $0.5 \leq \operatorname{Pr} \leq 2$ with non-uniform bottom heating where $\mathrm{Ha}=20$, $R a=10^{3}, \operatorname{Re}=60$. 
for $R o t=0^{\circ}, 90^{\circ}$ but minimum at $R o t=60^{\circ}$ for large Pr. From Figure 13(b), it is viewed that average bulk temperature goes up piercingly also for increasing $P r$. But highest average bulk temperature is seen for $R o t=0^{\circ}$ with increasing all $\mathrm{Pr}$ and minimum average temperature is seen for low $\operatorname{Pr}=0.5$, which happens as the fluid with the highest Pris skilled to carry away more heat from the source of heat and the dissipated with the out flow opening within the enclosure.

\section{Conclusions}

In this paper, Magneto-hydrodynamic mixed convection flow in a lid-driven trapezoidal enclosure $\left(\phi=30^{\circ}\right)$ for the effect of the rotations of heated triangular block or obstacle $\left(R o t=0^{\circ}-90^{\circ}\right)$ has been performed with the aid of governing non-dimensional parameters such as Rayleigh number, Hartmann number, Prandtl number and Reynolds number within trapezoidal cavity. The précis conclusions are as follows:

- Due to the rotations of heated triangular obstacle, a little effect of Reynolds number and Prandtl number being there with magnetic field is observed on the streamlines and isotherm structures within the enclosure. The eddy circulation cell's size decreases by the effect of heated triangular obstacle and clustered isotherm lines are observed around the heated triangular obstacle as well as the heated wall of the enclosure where $H a$ is fixed.

- Average Nusselt number varying rotations of triangular block increases owing to increase of Re and fixed $\mathrm{Ha}$ and also is higher and lesser for Rot $=90^{\circ}$ and $R o t=60^{\circ}$ respectively.

- Average bulk temperature enhances with the raise of $R e$ and is found higher for $R o t=0^{\circ}$. Moreover, average bulk temperature behaves conduction-like distribution for $R e=80$ and then starts convection flow for $R e>80$.

- The rate of heat transfer, that is, $N u_{a v}$ rises harshly by increasing $P r$ and maximum at $R o t=0^{\circ}, 90^{\circ}$ but minimum at $R o t=60^{\circ}$ for large Pr.

- Average bulk temperature goes up steadily for increasing $\operatorname{Pr}$ and is the highest for $R o t=0^{\circ}$ with increasing all Pr and minimum at low $\operatorname{Pr}=0.5$.

- Furthermore, heat conducting block, block with joule heating, nanofluids and also hybrid nanofluids can be used in a trapezoidal cavity as a future research work.

\section{Acknowledgements}

The authors like to state their thanks to the Department of Arts and Sciences, Ahsanullah Uiniversity of Science and Technology, Dhaka-1208, for giving the computer facility during this work.

\section{Conflicts of Interest}

The authors declare no conflicts of interest regarding the publication of this paper. 


\section{References}

[1] Aydin, O. (1999) Aiding and Opposing Mechanisms of Mixed Convection in a Shear Buoyancy Driven Cavity. International Communications in Heat and Mass Transfer, 26, 1019-1028. https://doi.org/10.1016/S0735-1933(99)00091-3

[2] Aydin, O. and Yang, W.J. (2000) Mixed Convection in Cavities with a Locally Heated Lower Wall and Moving Side Walls. Numerical Heat Transfer, Part A, 37, 695-710. https://doi.org/10.1080/104077800274037

[3] Guo, G. and Sharif, M.A.R. (2004) Mixed Convection in Rectangular Cavities at Various Aspect Ratios with Moving Isothermal Side Walls and Constant Flux Heat Source on the Bottom Wall. International Journal of Thermal Sciences, 43, 465-475. https://doi.org/10.1016/j.ijthermalsci.2003.08.008

[4] Oztop, H.F. and Dagtekin, I. (2004) Mixed Convection in Two-Sided Lid-Driven Differentially Heated Square Cavity. International Journal of Heat and Mass Transfer, 47, 1761-1769. https://doi.org/10.1016/j.ijheatmasstransfer.2003.10.016

[5] Hossain, M.A. and Gorla, R.S.R. (2006) Effect of Viscous Dissipation on Mixed Convection Flow of Water near Its Density Maximum in a Rectangular Enclosure with Isothermal Wall. International Journal of Numerical Methods for Heat and Fluid Flow, 16, 5-17. https://doi.org/10.1108/09615530610636928

[6] Luo, W.J. and Yang, R.J. (2007) Multiple Fluid Flow and Heat Transfer Solutions in a Two Sided Lid-Driven Cavity. International Journal of Heat and Mass Transfer, 50, 2394-2405. https://doi.org/10.1016/j.ijheatmasstransfer.2006.10.025

[7] Al-Amiri, A., Khanafer, K., Bull, J. and Pop, I. (2007) Effect of Sinusoidal Wavy Bottom Surface on Mixed Convection Heat Transfer in a Lid-Driven Cavity. International Journal of Heat and Mass Transfer, 50, 1771-1780.

https://doi.org/10.1016/j.ijheatmasstransfer.2006.10.008

[8] Saha, S., Saha, G. and Hasan, N. (2010) Mixed Convection in a Lid-Driven Cavity with Internal Heat Source. Proceedings of the 13 the Annual Paper Meet, Dhaka, $1-6$.

[9] Nasrin, R. and Parvin, S. (2011) Hydromagnetic Effect on Mixed Convection in a Lid-Driven Cavity with Sinusoidal Corrugated Bottom Surface. International Communications in Heat and Mass Transfer, 38, 781-789.

https://doi.org/10.1016/j.icheatmasstransfer.2011.03.002

[10] Bhattacharya, M., Basak, T., Oztop, H.F. and Varol, Y. (2013) Mixed Convection and Role of Multiple Solutions in Lid-Driven Trapezoidal Enclosures. International Journal of Heat and Mass Transfer, 63, 366-388. https://doi.org/10.1016/j.ijheatmasstransfer.2013.03.028

[11] Chattopadhyay, A. and Pandit, S.K. (2015) A Peclet Number Based Analysis of Mixed Convection for Lid-Driven Porous Trapezoidal Enclosure. Procedia Engineering, 127, 628-635. https://doi.org/10.1016/j.proeng.2015.11.354

[12] Basak, T., Roy, S. and Pop, I. (2009) Heat Flow Analysis for Natural Convection within Trapezoidal Enclosures Based on Heatline Concept. International Journal of Heat and Mass Transfer, 52, 2471-2483. https://doi.org/10.1016/j.ijheatmasstransfer.2009.01.020

[13] Kareem, A.K., Mohammed, H.A., Hussein, A.K. and Gao, S. (2016) Numerical Investigation of Mixed Convection Heat Transfer of Nanofluids in a Lid-Driven Trapezoidal Cavity. International Communications in Heat and Mass Transfer, 77, 195-205. https://doi.org/10.1016/j.icheatmasstransfer.2016.08.010

[14] Uddin, M.B., Rahman, M.M., Khan, M.A.H., Saidur, R. and Ibrahim, T.A. (2016) 
Hydromagnetic Double-Diffusive Mixed Convection in Trapezoidal Enclosure Due to Uniform and Nonuniform Heating at the Bottom Side: Effect of Lewis Number. Alexandria Engineering Journal, 55, 1165-1176. https://doi.org/10.1016/j.aej.2016.03.035

[15] Hossain, M.S. and Alim, M.A. (2013) MHD Free Convection within Trapezoidal Cavity with Uniformly Heated Bottom Wall. Annals of Pure and Applied Mathematics, 3, 41-55.

[16] Hossain, M.S. and Alim, M.A. (2014) MHD Free Convection within Trapezoidal Cavity with Non-Uniformly Heated Bottom Wall. International Journal of Heat and Mass Transfer, 69, 327-336. https://doi.org/10.1016/j.ijheatmasstransfer.2013.10.035

[17] Hossain, M.S., Alim, M.A. and Andallah, L.S. (2018) Numerical Investigation of Natural Convection Flow in a Trapezoidal Cavity with Non-Uniformly Heated Triangular Block Embedded inside. Journal of Advances in Mathematics and Computer Science, 28, 1-30. https://doi.org/10.9734/JAMCS/2018/43101

[18] Selimefendigil, F., Öztop, H.F. and Chamkha, A.J. (2017) Analysis of Mixed Convection of Nanofluid in a 3D Lid-Driven Trapezoidal Cavity with Flexible Side Surfaces and Inner Cylinder. International Communications in Heat and Mass Transfer, 87, 40-51. https://doi.org/10.1016/j.icheatmasstransfer.2017.06.015

[19] Gangawane, K.M. (2017) Computational Analysis of Mixed Convection Heat Transfer Characteristics in Lid-Driven Cavity Containing Triangular Block with Constant Heat Flux: Effect of Prandtl and Grashof Numbers. International Journal of Heat and Mass Transfer, 105, 34-57. https://doi.org/10.1016/j.ijheatmasstransfer.2016.09.061

[20] Gangawane, K.M., Oztop, H.F. and Abu-Hamdeh, N. (2018) Mixed Convection Characteristic in a Lid-Driven Cavity Containing Heated Triangular Block: Effect of Location and Size of Block. International Journal of Heat and Mass Transfer, 124, 860-875. https://doi.org/10.1016/j.ijheatmasstransfer.2018.03.079

[21] Selimefendigil, F. and Öztop, H.F. (2018) Modeling and Optimization of MHD Mixed Convection in a Lid-Driven Trapezoidal Cavity Filled with Alumina-Water Nanofluid: Effects of Electrical Conductivity Models. International Journal of Mechanical Sciences, 136, 264-278. https://doi.org/10.1016/j.ijmecsci.2017.12.035

[22] Mehmood, Z. (2019) Numerical Simulations and Linear Stability Analysis of Mixed Thermomagnetic Convection through Two Lid-Driven Entrapped Trapezoidal Cavities Enclosing Ferrofluid Saturated Porous Medium. International Communications in Heat and Mass Transfer, 109, Article ID: 104345.

https://doi.org/10.1016/j.icheatmasstransfer.2019.104345

[23] Haq, R.U. and Aman, S. (2019) Water Functionalized CuO Nanoparticles Filled in a Partially Heated Trapezoidal Cavity with Inner Heated Obstacle: FEM Approach. International Journal of Heat and Mass Transfer, 128, 401-417. https://doi.org/10.1016/j.ijheatmasstransfer.2018.08.088

[24] Çolak, E., Öztop, H.F. and Ekici, Ö. (2020) MHD Mixed Convection in a Chamfered Lid-Driven Cavity with Partial Heating. International Journal of Heat and Mass Transfer, 156, Article 11990. https://doi.org/10.1016/j.ijheatmasstransfer.2020.119901

[25] Singh, S. and Sharif, M.A.R. (2003) Mixed Convective Cooling of a Rectangular Cavity with Inlet and Exit Openings on Differentially Heated Side Walls. Numerical Heat Transfer, Part A, 44, 233-253. https://doi.org/10.1080/716100509

[26] Corvaro, F. and Paroncini, M. (2008) A Numerical and Experimental Analysis on the Natural Convection Heat Transfer of a Small Heating Strip Located on the Floor 
of a Square Cavity. Applied Thermal Engineering, 28, 25-35.

https://doi.org/10.1016/j.applthermaleng.2007.03.018

[27] Dechaumphai, P. (1999) Finite Element Method in Engineering. 2nd Edition, Chulalongkorn University Press, Bangkok.

[28] Taylor, C. and Hood, P. (1973) A Numerical Solution of the Navier-Stokes Equations Using Finite Element Technique. Computer and Fluids, 1, 73-100.

https://doi.org/10.1016/0045-7930(73)90027-3

[29] Reddy, J.N. (1985) An Introduction to the Finite Element Method. McGraw-Hill, New York. 


\section{Nomenclature}

$B_{0}$ : Magnetic induction

$C_{p}$ : Specific heat at constant pressure $(\mathrm{J} / \mathrm{kg} \cdot \mathrm{K})$

g. Gravitational acceleration $\left(\mathrm{m} / \mathrm{s}^{2}\right)$

$h$ : Convective heat transfer coefficient $\left(\mathrm{W} / \mathrm{m}^{2} \cdot \mathrm{K}\right)$

$k$. Thermal conductivity of fluid(W/m K)

$L$ : Langth or base of trapezoidal cavity $(\mathrm{m})$

$H$ : Height of trapezoidal cavity (m)

$N$ : Total number of nodes

$N u_{a r}$ : Average Nusselt number

$\theta_{a v}$ : Average bulk temperature

$P$ : Non-dimensional pressure

$p$ : Pressure, $\mathrm{Pa}$

Pr. Prandtl number

Ra: Rayleigh number

Ha: Hartmann number

Re: Reynolds number

T: Non-dimensional temperature

$T_{i}$ : Temperature of insulated top wall $(\mathrm{K})$

$T_{h}$ : Temperature of hot bottom wall (K)

$T_{c}$ : Temperature of cold side wall (K)

$U: \mathrm{x}$ component of dimensionless velocity

$u$ : $x$ component of velocity $(\mathrm{m} / \mathrm{s})$

$V:$ y component of dimensionless velocity

v. y component of velocity $(\mathrm{m} / \mathrm{s})$

$U_{0}$ : Lid velocity

$X, y$. Distance along Cartesian coordinates

$X, Y$ : Dimensionless distance along Cartesian Coordinates

\section{Greek Symbols}

$\alpha$ : Thermal diffusivity $\left(\mathrm{m}^{2} / \mathrm{s}\right)$

$\beta$ : Coefficient of thermal expansion $\left(\mathrm{K}^{-1}\right)$

$\rho$. Density of the fluid $\left(\mathrm{kg} / \mathrm{m}^{3}\right)$

$\Delta \theta$. Temperature difference

$\Theta$ : Dimensionless fluid temperature

M: Dynamic viscosity of the fluid (Pa.s)

$\Psi$ : Stream function

$\phi$ Inclination angles

$v$. Kinematic viscosity of the fluid $\left(\mathrm{m}^{2} / \mathrm{s}\right)$

$\sigma$. Fluid electrical conductivity $\left(\Omega^{-1} \cdot \mathrm{m}^{-1}\right)$ 


\section{Subscripts}

av. average

\section{Abbreviations}

Rot: Different rotations of heated triangular block 